\title{
FENOMENA DINAMIKA KEPUBLIKAN DALAM HIRARKI RUANG KAWASAN PUBLIK KOTA
}

\author{
Ully Irma Maulina Hanafiah, Doddy Friestya Asharsinyo \\ Universitas Telkom \\ Email : ullyrmaulinafia@telkomuniversity.ac.id
}

The public area of the city in general is currently experiencing rapid development due to economic growth and the influence of globalization. The public space is formed based on economic, social, political cultural interests, as well as developments and changes that occur in the current public space, making it limited and cannot be accessed optimally by the wider community. This is caused by the hierarchy of public spaces that are formed based on the functions that surround them. The purpose of this study is to reveal the phenomenon of public hierarchy in urban space in the context of its changes. This research is descriptive-analytical and based on theoretical and empirical elaboration. This approach is used to read public spaces in urban areas to get a reference for the interpretation of theoretical relationships from an empirical condition.

Keywords: hierarchy, public space, boundaries, dynamics

Abstrak : Ruang kawasan publik kota pada umumnya pada saat ini mengalami perkembangan yang pesat akibat pertumbuhan ekonomi dan pengaruh globalisasi. Ruang kawasan publik terbentuk berdasarkan kepentingan ekonomi, sosial, budaya politik, serta perkembangan dan perubahan yang terjadi pada ruang kawasan publik saat ini menjadikannya terbatas dan tidak bisa diakses maksimal oleh masyarakat luas. Hal ini diakibatkan oleh hirarki ruang publik yang terbentuk berdasarkan fungsi yang melingkupinya. Tujuan penelitian ini adalah mengungkap fenomena hirarki kepublikan pada ruang kawasan kota dalam konteks perubahannya. Penelitian ini bersifat deskriptif-analitis dan berlandas pada elaborasi empiris secara teoritik dan empiris. Pendekatan ini digunakan untuk membaca ruang-ruang publik pada ruang kawasan kota untuk mendapatkan acuan bagi intepretasi hubungan teoritik dari suatu kondisi empiris.

Kata kunci : hirarki, ruang publik, batasan, dinamika

\section{PENDAHULUAN}

Ruang publik di kawasan kota besar telah banyak berkembang melalui perbaikan sarana dan prasarana infrastrukturnya, namun dalam pengelolaannya lebih banyak melibatkan pihak swasta yang cenderung membatasi aksesibilitas ruang publik tersebut. Salah satu barometer kualitas hidup sebuah kota adalah ranah publik. Ranah publik diwadahi melalui ruang terbuka/publik yang mempertemukan antar komunitas warga kota. Ranah publik menjadi pelebur segala 
kepentingan, baik warga, penguasa, hingga pengusaha. Dalam perkembangan nya saat ini, ruang publik dapat diakses dan digunakan bersama-sama berupa jalan, taman, pusat perbelanjaan, kampus, rumah sakit, fasilitas transportasi umum (halte), museum dan sebagainya

Ruang publik sebagai wadah interaksi sosial telah berubah makna dan nilainya sebagai ruang yang lebih mementingkan kepentingan individu dan golongan tertentu, dan hanya untuk memperoleh kepuasaan konsumtif masyarakat urban. Ruang publik bukan lagi sebagai sarana komunikasi untuk membentuk proses peradaban sosial manusia, tapi hanya untuk kebutuhan masyarakat urban yang hendak mencari kepuasaan diri. Pada umumnya perkembangan ruang publik dari masa ke masa memiliki fungsi sebagai ruang interaksi sosial bagi masyarakat, ruang kegiatan ekonomi rakyat dan tempat apresiasi budaya. Ruang merupakan elemen yang sangat penting dalam Arsitektur. Ruang (space) berasal dari Bahasa latin, yaitu spatium yang berarti ruangan atau luas (extent). Jika dilihat dalam Bahasa Yunani dapat diartikan sebagai tempat (topos) atau lokasi (choros) yaitu ruang yang memiliki ekspresi kualitas tiga dimensi. Menurut Aristoteles, ruang adalah suatu yang terukur dan terlihat, dibatasi oleh kejelasan fisik, enclosure yang terlihat sehungga dapat dipahami keberadaannya dengan jelas dan mudah.

\section{METODE PENELITIAN}

Penelitian ini bersifat deskriptif-analitis dan berlandas pada elaborasi empiris secara teoritik dan empiris. Pendekatan ini digunakan untuk membaca ruang-ruang publik pada ruang kawasan kota untuk mendapatkan acuan bagi intepretasi hubungan teoritik dari suatu kondisi empiris.

\section{HASIL DAN PEMBAHASAN}

Kata 'Publik' berasal dari kata latin, yaitu Publicus. Pemaknaan kata Publicus sebagai kata benda berupa satuan polis atau warga yg menjadi bagian negara, sebagai kata sifat merupakan kehendak warga (umum). Publicus juga mengandung arti terkait dengan kekuasaan para pejabat negara. Polis yg merupakan ranah publik menempatkan manusia ke dalam manusia-manusia politis, yaitu berbicara-bertindak dalam kesalingan dan kebersamaan. Fenomena 'kebersamaan' ini terkandung dalam wujud dan bentuk ruang publik yang dapat dipahami dan ditujukan dari pengalaman manusia, untuk menjelaskan situasi manusia, peristiwa dan pengalaman, "sebagai sesuatu yang muncul dan hadir dalam kebersamaan. (Von Eckartsberg, 1980). Dalam proses berkembangnya apa yang disebut "polis" terdapat hal-hal pokok yang dibahas dalam ruang publik yang disebut sebagai "res publica" yaitu hal kehidupan publik rakyat atau warga dimana penanganannya ada dalam otonomi warga. Jika prinsip res publica ini sebagai ruang interaksi terpenuhi secara harmonis dengan fungsi res private pada jalan umum, ruang terbuka kota dan fungsi publik kota lainnya, maka akan terbentuklah apa yang Rob Krier (1985) sebut sebagai the true city atau civitas. 


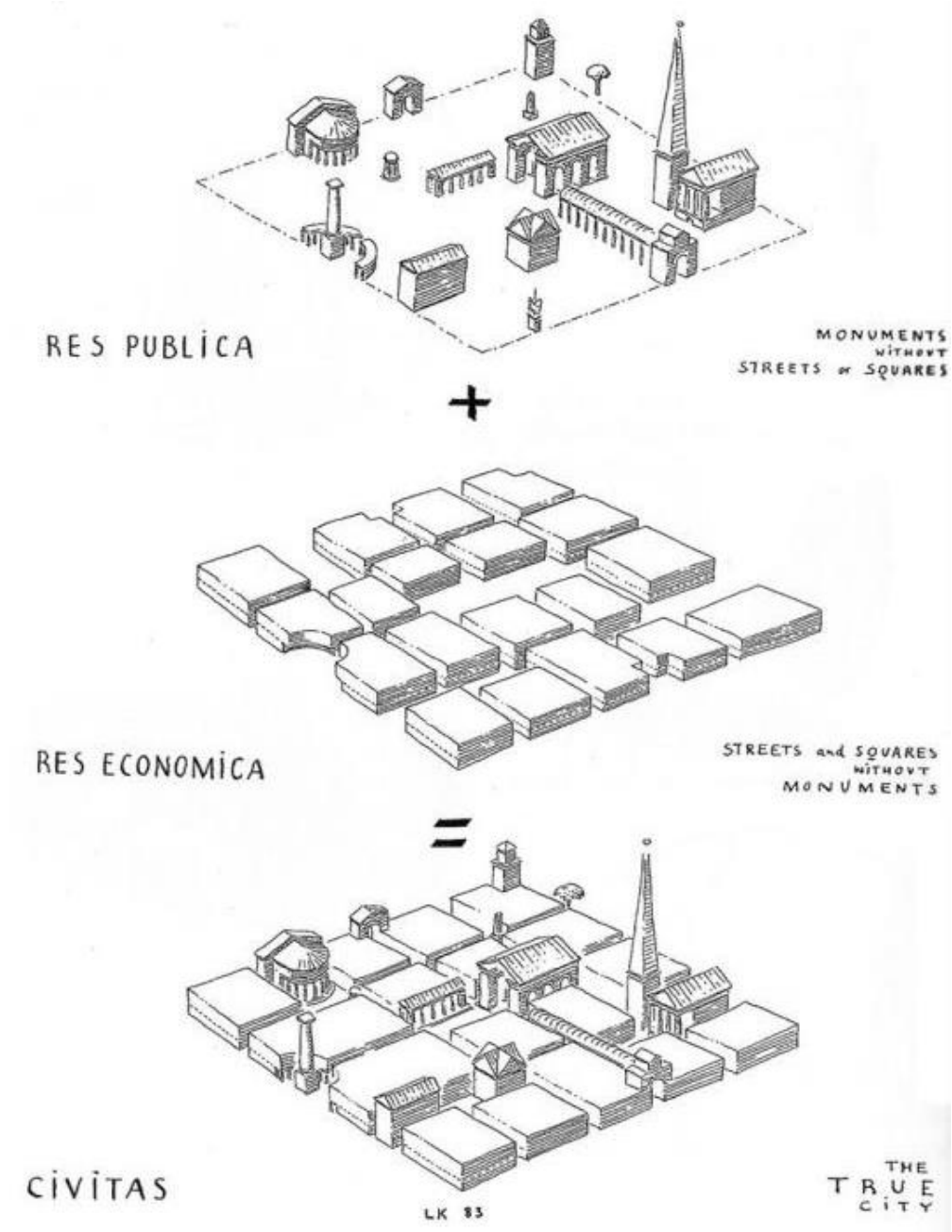

Gambar 1. The True City oleh Rob Krier (1985)

Pada pertengahan abad ke-20 mulai bangkitnya kapitalisme negara, industri budaya dengan produksi ekonomi dan bisnis skala besar mengambil alih ruang publik, diskusi publik yang rasional menjadi kehilangan tempatnya dalam masyarakat secara keseluruhan. Pertumbuhan media komersial, mengubah publik (warga) menjadi konsumen yang pasif. Mereka menjadi tenggelam dalam isu-isu yang bersifat privat. Dalam ranah publik kapitalisme kontemporer, opini publik nya diatur oleh para elite politik, ekonomi, dan media yang dominan dan sebagian besar mewakili kepentingan privat. Alan McKee melihat perubahan ruang publik tersebut dalam 2 cara pandang, yakni modern dan postmodern. Modern cenderung menamai perubahan tersebut sebagai 'degradasi ruang publik' dan suatu asumsi bahwa suatu 'ruang publik ideal' perlu diwujudkan. Postmodern menyebut perubahan tersebut sebagai proses diferensiasi: publik yang berbeda menciptakan ruang publik yang berbeda. 
Pada umumnya perkembangan ruang publik dari masa ke masa memiliki fungsi sebagai ruang interaksi sosial bagi masyarakat, ruang kegiatan ekonomi rakyat dan tempat apresiasi budaya. Kebutuhan masyarakat di ruang terbuka publik selalu berubah, sejalan dengan perkembangan zaman dan adanya pengaruh kebutuhan:

1. Sosial budaya : Kebutuhan manusia mengekspresikan dirinya kepada sesama manusia dan kepada Tuhannya.

2. Politik : kebutuhan akan suatu simbol dari kota, negera, kekuasaan, pemerintah atau kekuatan rakyat

3. Ekonomi : berkumpulnya masyarakat pada suatu tempat akan mendorong munculnya aktifitas ekonomi, misalnya pasar.

Sebagai sebuah artefak terbesar, kota terbentuk dari kumpulan bangunan dan orang (Kostof, 1991), salah satu barometer kualitas hidup sebuah kota adalah ranah publik.

Ranah publik sebagai tempat terbuka yang mempertemukan antar komunitas warga suatu kota, ranah publik menjadi pelebur segala kepentingan, baik warga, penguasa, hingga pengusaha. Suatu ruang dipahami dalam gagasan rasional, ruang publik kota bukan sesuatu yang kosong tanpa arti. Ruang publik kota adalah ruang yang mempunyai relasional antara historitas dan hidup manusia kota. Dalam kehidupan modernisasi sering ditemukan sebagai heterotopia (Foucault,1967). Lefebre (1980) mengatakan dinamika kota dilihat sebagai ruang sosial, yaitu ruang sebagai produk sosial dengan berbagai macam aktifitas orang di dalamnya. Baginya, ranah publik menunjuk pada "jaringan keterlibatan dan ruang sosial tertentu yang menyangga kerja sama dan koordinasi civitas", terutama dalam interaksi antara kota besar dan ekonomi. Jadi ruang kota adalah ranah publik apabila ruang kota tersebut memproduksi ruang sosial ketika masyarakat beraktifitas didalamnya. Pengertian ruang publik sebagai lingkup spasial (sphere) menjadi locus partisipasi warganegara, dimana eksistensi manusia bisa menghadirkan diri dalam kebebasannya. Ruang publik tersebut berkaitan dengan aktivitas suatu komunitas bahasa dan akal sehat manusia, maka ia merupakan sebuah ruang sosial yang terbentuk lewat interaksi dan komunikasi sosial (Arendt,2000). Jan Gehl (1987) menyatakan bahwa Indikator ruang interakasi berdasarkan terjadinya kontak antara manusia, sebagaimana dijelaskan dalam gambar berikut.

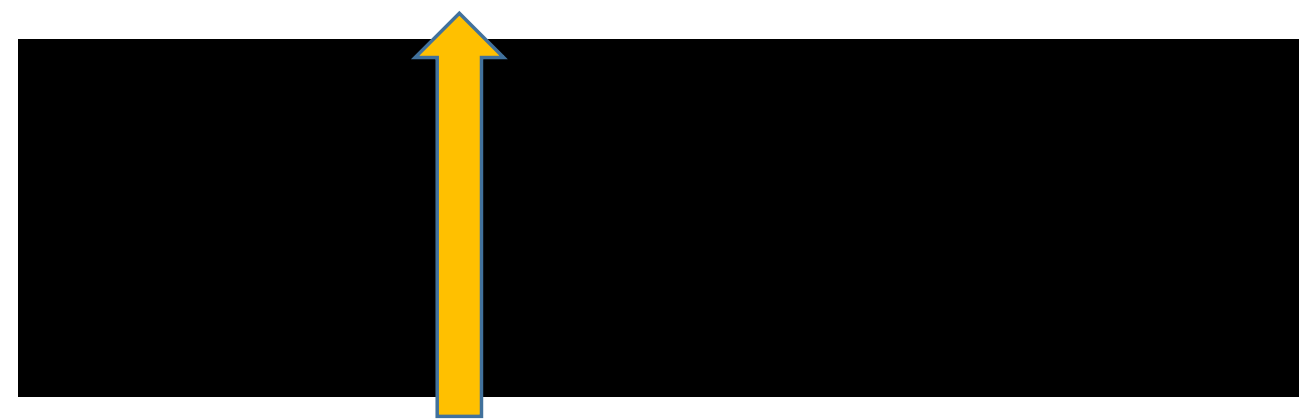


Jurnal Potensi

Program Studi Magister Perencanaan Wilayah Universitas Batam

Volume I, Issue 1, Maret 2021, Page 16-22

Gambar 2.Diagram Tingkat Interaksi Berdasarkan Kontak yang Terjadi

Sumber : Life Between Building (1987)

Sutedjo (1992), bahwa interaksi adalah kunci dari semua kehidupan sosial tanpa adanya interaksi tidak mungkin ada kehidupan bersama. Hal ini memperlihatkan peran ruang bersama sangat penting : Ruang terbentuk dalam konteks sosial yaitu dari proses komunikasi antar manusia dan ruang berperan untuk mewadahi hubungan antar manusia

Pada proses pembentukan ruang terbuka berdasarkan aktivitasnya, konsep Eropa menjadikan ruang kota sebagai tujuan dari pembentukan massa-massa bangunan yang melingkupinya, sedangkan konsep kota-kota di Asia cenderung menjadikan ruang kota adalah akibat dari pembentukan massa bangunan. (Markus Zahnd, 1999). Ruang publik kota-kota di Indonesia, tidak mengenal adanya konsepsi kepemilikan publik bagi warga kota secara keseluruhan dari masa ke masa (Pra VOC, Kolonial Hindia Belanda dan Kemerdekaan). Faktor budaya dan sejarah bermukim masyarakat di Indonesia berangkat dari tipologi kampung bukan dari tipologi kota. (Jo, Santoso, 2017). Ruang publik di Indonesia cenderung dikuasai oleh kekuasaan sepanjang masa penguasaan Pra VOC, Kolonial Hindia Belanda dan Kemerdekaan. Habermas (1989), menyingkapi hal tsb dalam konteks teori kekuasaan dengan membagi dua jenis ruang publik: Ruang publik yang tidak dikooptasi oleh kekuasaan dan Ruang publik yang dikooptasi oleh kekuasaan.
Ruang publik yang tidak dikooptasi oleh kekuasaan, yaitu ruang publik yang tumbuh dari dunia-kehidupan. Aktor dalam ruang publik yang tidak dikooptasi oleh kekuasaan adalah para pribumi, karena mereka berasal dari publik itu sendiri dan memiliki akar yang mendalam pada dunia-kehidupan, contohnya masyarakat pd ruang-ruang-publik yang terbentuk pada pemukiman masyarakat yang lebih tradisional.

Ruang publik yang dikooptasi oleh kekuasaan yaitu ruang publik didominasi oleh aktor pemakai. Aktor yang tidak tumbuh dari publik tapi tampil didepan publik dan menduduki ruang publik. Pihak-pihak swasta dari sektor ekonomi dan bisnis skala besar serta organisasi pemerintah yang dominan yang dapat mengambil alih ruang publik secara formal.

Pada kenyataannya ruang publik tidak mutlak bersifat sosial atau umum (terbuka) yang dapat dimasuki siapa saja untuk melakukan aktivitas interaksi didalamnya secara bebas. Sebagai tempat yang bersifat publik yang mana terdapat kegiatan interaksi individu maupun kelompok terjadi didalamnya, terdapat adanya batasan (hirarki) untuk menggunakan ruang publik tersebut.

\section{KESIMPULAN}

Kesimpulan dari uraian diatas adalah sebagai berikut : 
1. Hakikat ranah publik yang sejak awal terbentuk meruncing kepersoalan peran politis masyarakat warga dalam demokrasi mulai melebar ke persoalan kebudayaan dalam arti luas.

2. Pada umumnya perkembangan ruang publik dari masa ke masa memiliki fungsi sebagai ruang interaksi sosial bagi masyarakat, ruang kegiatan ekonomi rakyat dan tempat apresiasi budaya. Kebutuhan masyarakat di ruang terbuka publik selalu berubah, sejalan dengan perkembangan zaman dan adanya pengaruh kebutuhan sosial budaya, politik dan ekonomi.

3. Memasuki abad ke-20 terjadi apa yang disebut krisis ruang publik oleh kekuatan-kekuatan kultur kapitalisme kontemporer yang dipicu oleh bangkitnya masyarakat massa akibat industrialisasi.Hakikat ranah publik seakan beralih makna bukan lagi sebagai sarana komunikasi untuk membentuk proses keadaban sosial manusia, tapi hanya sekedar untuk kebutuhan masyarakat urban yang hendak mencari kepuasan.

4. Hirarki kepublikan yang pada suatu ruang publik berbeda-beda tergantung dari penggunaan dan pemilik ruang nya, dimiliki oleh pemerintah untuk umum atau dimiliki oleh institusi tertentu.

\section{DAFTAR ISI}

1] Carr, Stephen, 1995, Public Spaces, John Wiley \& Sons.

2] Damajani, Dhian (2008), Gejala Ruang Ketiga (Thirdspace) di kota Bandung, Paradoks dalam Ruang
Publik Urban Kontemporer, Disertasi, ITB.

3] Dick, H.W. and Rimmer P.J., 1997, Beyond The Third World City : The New Urban Geography Of South-East Asia. Urban Studies.

4] Ekomadyo, Agus (2009), Pengendalian Kualitas Arsitektur Kota Pada Ruang Publik di Kota Pekanbaru, Disertasi, ITB.

5] Groat, Linda and Wang, David. 2002. Architectural Research Methods. John Wiley \& Sons.

6] Gehl, Jan, 1987, Life Beetwen Building, Island Press.

7] Krier, Rob, Urban Space, 1979, New York Press.

8] Karsono, Bambang , 2013, Keterikatan Tempat Pada Promenad Tebing Sungai Di Malaysia, Dissertation, USM, Malaysia.

9] Kostof, Spiro, 1999, The City Shaped, Thames and Hudson, London.

10] Lefebre, Henri, The Production Of Space, 1991, Wiley

11] Louis Wirth. 1938, Urbanism as a Way of Life.. The American Journal of Sociology, Vol. 44, No. 1.

12] Norberg-Schulz, Christian, 1988, Architecture : Meaning and Place, Rizzoli Int. Publication, New York.

13] Neuman, W. Lawrence. 2006. Social Research Methods, Qualitative And Quantitative Approaches, Sixth Edition. Person International Edition.

14] Puspitasari, Popi (2014), Keterulangan Kehadiran sebagai basis pemanfaatan ruang publik di kampung Luar Batang, Jakarta Utara, Disertasi, UGM. 
15] T.M. De Jong And D. J. M. Van Der Voordt. 2002. Ways To Study And Research, Urban, Architectural and Technical Design. DUP Science.

16] Rapoport, Amos 1980, Human Aspects Of Urban Form, Pergamon, Press, Oxford.

17] Rossi, A, 1982, The Architecture Of The City, Cambridge, MIT Press.

18] Salura, Purnama; Fauzi, Bachtiar. (2012). The Ever-rotating Aspects of Function-Form-Meaning in Architecture. Journal of Basic and Applied, 7086-7090.

19] Siregar, Sandi Aminuddin ,1990. Bandung-The Architecture of a City in Development: Urban Analysis of a Regional Capital as a Contribution to the Present Debate on Indonesian Urbanity and Architectural Identity. Dissertation. Katholieke Universiteit Leuven, Leuven.

20] Supriharjo, Rima Dewi , 2004, Developing Land Value Concept in Ampel Heritage Area Surabaya City, Dissertation, UGM.

21] Wibisono, Bambang Hari , 2001, Transformation of Jalan Malioboro, Yogyakarta: The Morphology and Dynamics of a Javanese Street. Dissertation. Faculty of Architecture, Building and Planning, The University of Melbourne. 